\title{
Exploitation of northern peatlands and biodiversity maintenance: a conflict between economy and ecology
}

\author{
Steve Chapman ${ }^{1}$, Alexandre Buttler ${ }^{2,3}$, André-Jean Francez ${ }^{4}$, Fatima Laggoun-Défarge ${ }^{5}$, Harri Vasander ${ }^{6}$ \\ Michael Schloter ${ }^{7}$, Jean Combe ${ }^{3}$, Philippe Grosvernier ${ }^{8}$, Hauke Harms ${ }^{9}$, Daniel Epron ${ }^{10}$, Daniel Gilbert ${ }^{10}$, \\ and Edward Mitchell ${ }^{3,11}$
}

Peatlands are ecosystems of exceptional conservation value because of their beauty, biodiversity, importance in global geochemical cycles, and the paleoenvironmental records they preserve. Commercial extraction and drainage for forestry or agriculture have caused the destruction of many peatlands, especially in or close to urban areas of the northern temperate zone. Are these commercial and environmental interests irreconcilable? A close analysis suggests that limited peat extraction may actually increase biodiversity in some cases, and may be sustainable over the long term. As we learn more about how peatlands spontaneously regenerate following disturbance, and what conditions govern the re-establishment of a diverse community and the ability to sequester carbon, we increase our chances of being able to restore damaged peatlands. Preserving the chronological records hidden in the peat profile, the natural heritage value of peatlands, and the bulk of sequestered carbon, however, will remain incompatible with any form of exploitation.

Front Ecol Environ 2003; 1(10): 525-532

P eatlands are the most widespread type of wetlands in the world, representing $50-70 \%$ of global wetlands. The impact of human activities on ecosystems can hardly be illustrated more dramatically than in the contrast between a pristine peatland and the same ecosystem degraded by peat mining into an endless brown desert surface (Figures 1 and 2). The difference illustrates the

\section{In a nutshell:}

- Peatlands have high commercial and ecosystem values

- Exploitation has caused the loss of many peatlands, especially near urban areas

- In some cases these conflicting interests may be reconciled, and some exploitation may actually increase biodiversity

- The study of regeneration patterns and processes will improve our ability to restore damaged peatlands and provide guidelines for sustainable use

\footnotetext{
${ }^{1}$ The Macaulay Institute, Craigiebuckler, Aberdeen, UK; (S.Chap man@macaulay.ac.uk) ${ }^{2}$ Laboratoire de Chrono-Ecologie, University of Franche-Comté, Besançon, France; ${ }^{3}$ Swiss Federal Research Institute, Lausanne, Switzerland; ${ }^{4}$ Equipe Interactions Biologiques et Transferts de Matières, University of Rennes, Rennes, France; ${ }^{5}$ Institut des Sciences de la Terre d'Orleans, University of Orléans, Orléans, France; ${ }^{6}$ Dept of Forest Ecology, University of Helsinki, Helsinki, Finland; ${ }^{7}$ GSF-National Research Center for Environment and Health, Institute of Soil Ecology, Neuherberg, Germany; ${ }^{8}$ LIN'eco, Reconvilier, Switzerland; 'Swiss Federal Institute of Technology, Lausanne, Switzerland; ${ }^{10}$ Laboratoire de Biologie et Ecophysiologie, University of Franche-Comté, Besançon, France; ${ }^{11}$ Dept of Biological Sciences, University of Alaska, Anchorage, AK(afeam@uaa.alaska.edu)
}

importance of the conflict between conservation and the industrial exploitation of natural resources, and the different ways people appreciate natural ecosystems.

Peatlands represent a vital habitat for many unique species, play an important role as a pool and sink for carbon $(\mathrm{C})$, contribute to the equilibration of the water cycle, and contain a wealth of information in the remains of plants, animals, and atmospheric particles deposited and stored in the peat profile (Gorham 1991b; Barber 1993). Limited exploitation may provide timber, food for subsistence lifestyles, and other plant products, some of medicinal value. However, most of the time these ecosystems have also been seen as a valuable natural resource in the form of peat itself, which has many uses, including as a fuel, animal bedding, and a growth substrate in horticulture and agriculture.

These conflicts raise a number of questions that we must address before we can decide if the exploitation of peatlands can be sustainable over the long term (Schilstra 2001). Where are peatlands located? How much peat is there to be exploited? How does peat extraction affect the global C budget, water cycles, climate, and biodiversity? Can extraction be done sustainably, and can damaged peatlands be restored to their original condition? How long does it take to build up a harvestable amount of peat?

\section{From exploitation to restoration and sustainability}

While many of these questions do not have a definitive answer, our understanding of peatland ecology has improved substantially in recent years. For example, 


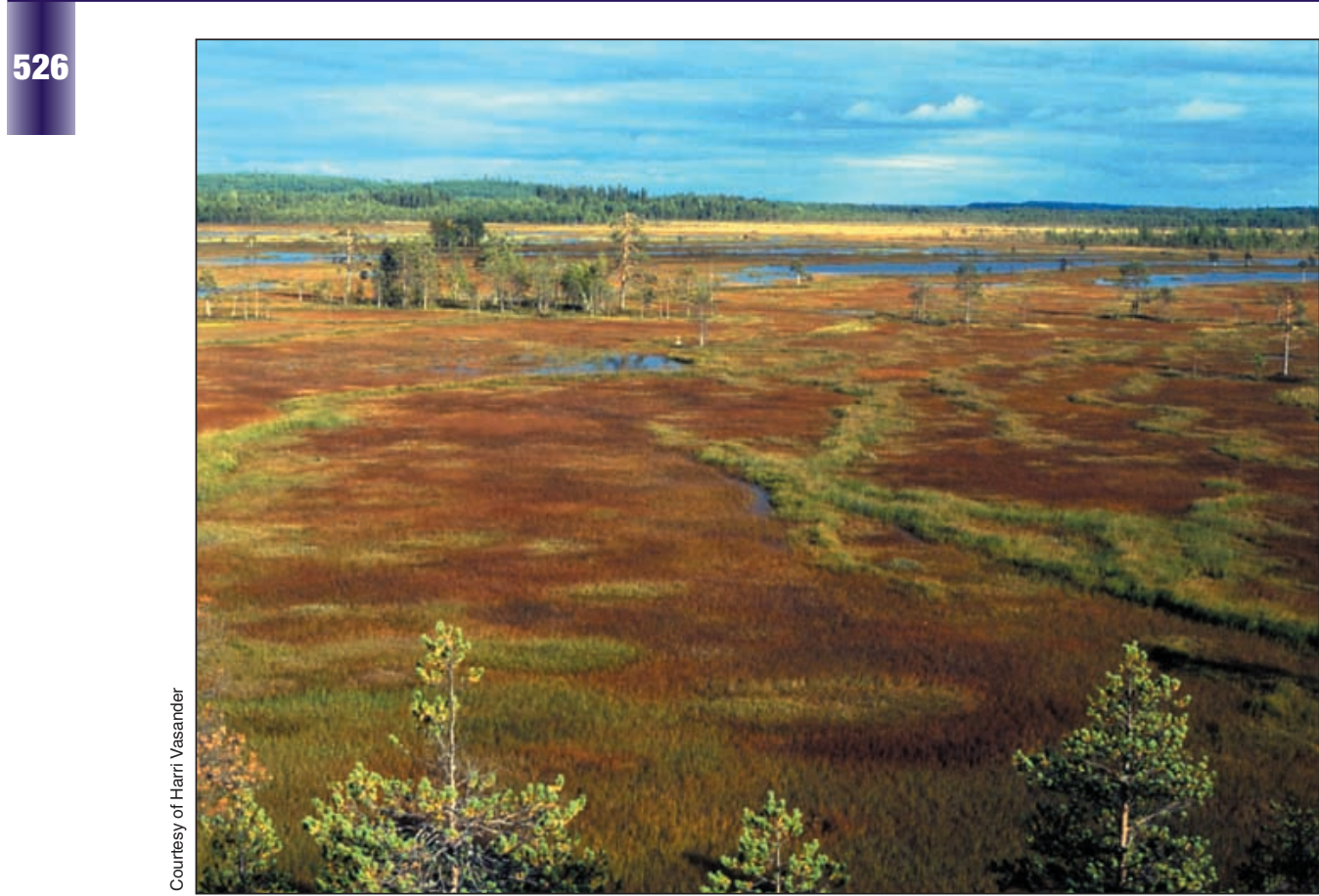

mitted to making peat exploitation a truly sustainable practice. There are reasons to hope that the management of peatlands could soon be a good test case of a successful collaboration between conservationists, scientists, and industry, and an example for the management of other ecosystems, such as forests and the sea.

In this review we will present some general facts about northern peatlands and the history of their exploitation, analyze how peat exploitation may be made sustainable and compatible with conservation goals, outline current research needs, and present a research initiative aimed at reconciling commercial exploitation of peat with the preservation of biodiversity in peatland ecosystems - the EC-funded project Figure 1. A pristine peatland. RECIPE.

research has shown that under some conditions, Sphagnum mosses (also called peat mosses), the main peat builders, can reestablish on former surfaces of bare peat (Grosvernier et al. 1995; Figures 3 and 4). Although much more needs to be understood about these processes, it is possible to envision the active restoration of bare mined peatlands (Grosvernier et al. 1995; Girard et al. 2002; Gorham and Rochefort 2003).

Until recently, the conflict between conservationists and the peat industry seemed to be irreconcilable. Indeed, preserving the archives and, more generally, the natural heritage value and the bulk of sequestered $\mathrm{C}$ of peatlands will remain incompatible with any form of exploitation. However, a closer analysis suggests that, at least in some cases, limited peat extraction can actually increase biodiversity, and may be sustainable in the long term. Much work remains to be done, but at last both parties are working together to solve the problem. This is well illustrated by the recent publication of The wise use of mires and peatlands (Joosten and Clarke 2002), a landmark book which was the product of a joint effort by the International Mire Conservation Group (a group of scientists aiming to preserve peatlands) and the International Peat Society, which is involved in developing the commercial exploitation of peatlands. Several leading companies within the peat industry now seem clearly com-

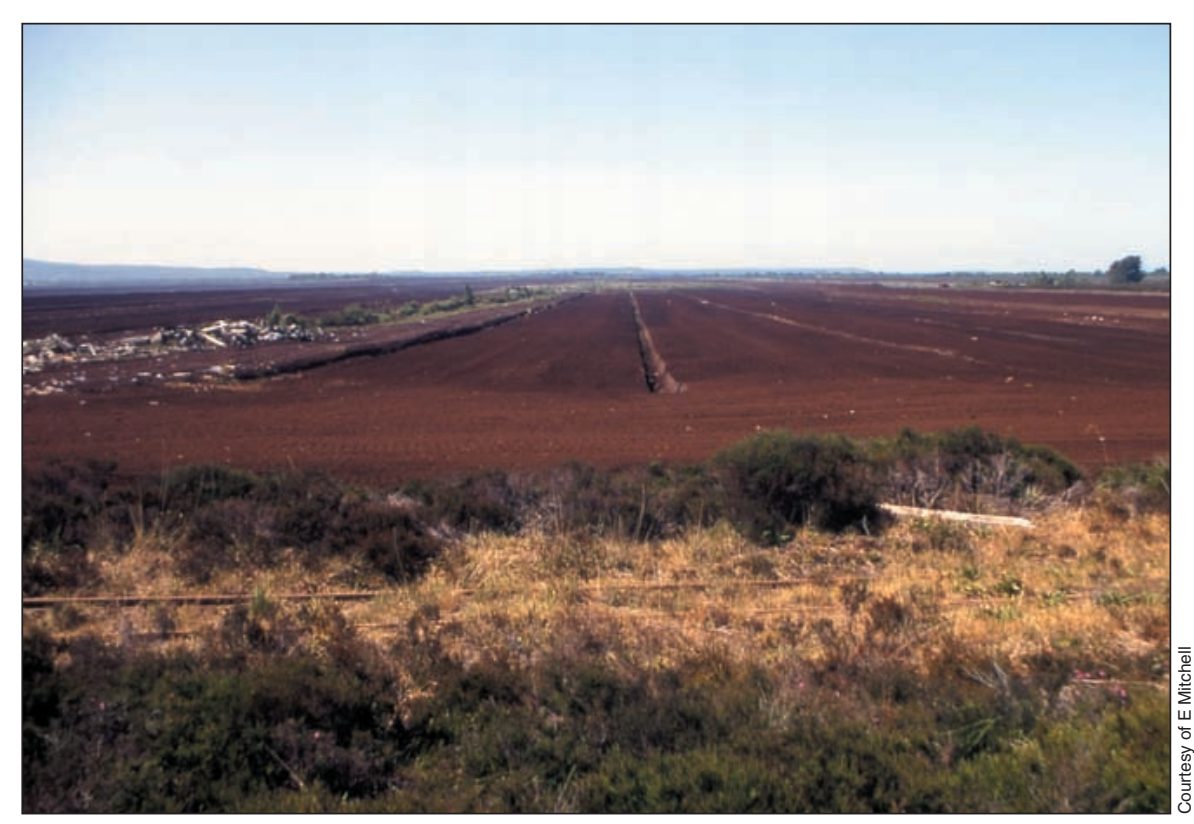

Figure 2. Example of an Irish peatland in which peat is currently being harvested on an industrial scale. This type of exploitation is the most damaging to peatlands, as all the vegetation is removed. 
million ha and hold 455 billion metric tons of C - slightly less than the amount contained in all living organisms, or in all atmospheric $\mathrm{CO}_{2}$ (Gorham 1991b).

This important $\mathrm{C}$ pool has been slowly eroded by humans through drainage, conversion to agriculture and forestry, and peat mining. The global rate of loss of active peatlands (where peat is accumulating naturally) has been estimated to be $0.1 \%$ per year (Joosten and Clarke 2002). Within Europe, however, the losses have been much greater; there, $52 \%$ of active peatlands have now been lost, and in certain countries such as Denmark and the Netherlands, where active peatlands once covered over $20 \%$ of the land surface, virtually all peatlands are gone (Joosten and Clarke 2002).

Despite these losses, active northern peatlands continue to fix $\mathrm{C}$ at a rate of approximately 70 million metric tons per year (Gorham 1991b; Clymo et al. 1998); at the same time, they generally release roughly 50 million metric tons of methane per year (Gorham 1991b). This emission is very important in determining peatlands' role in global warming, since methane is about 70 times more effective as a greenhouse gas than $\mathrm{CO}_{2}$ on a 20-year time scale (and 20 times greater on a 100-year time scale). It would appear therefore that active peatlands are positive contributors to global warming, and that peatland utilization actually reduces this contribution, at least in the short term (Schilstra 2001).

\section{Past and present uses and abuses}

Peat has probably been used for millennia as a fuel in northern treeless areas such as the Scottish islands and Ireland, where the practice continues to this day. Industrial extraction of fuel peat began in Europe in the 19 th century with the invention of peat-working machines (Lappalainen 1996). In southern Sweden, the cultivation of peat soils dates back to the early Iron Age (Egelmark 2000). The conversion of peatlands to agricultural use was evident in the Netherlands as early as the 10th to 14th centuries (van den Bos pers comm), while in England, medieval fuel peat workings gave rise to the flooded lakes of the Norfolk Broads. Extensive drainage of bogs and fens for agricultural use in Europe began in the 17 th century. Since the middle of the 20th century, large peatland areas have been drained for forestry.

In 1995, 71 million $\mathrm{m}^{3}$ of energy peat were produced (Lappalainen 1996) and the C flux due to combustion is estimated to be 2.6 million metric tons per year, equivalent to only about $0.4 \%$ of the 6.5 billion metric tons of flux due to all fossil energies (Gorham 1991b). Today, half of all peat extracted is used in horticulture or for soil conditioning, and practically all Canadian peat is used in this way (Lappalainen 1996). How much of this $\mathrm{C}$ is converted to $\mathrm{CO}_{2}$ is unknown.

Of the active peatlands lost over time in the non-tropical world, $50 \%$ has been to agriculture, $30 \%$ to forestry, $10 \%$ to peat extraction, and the remainder to urbaniza-

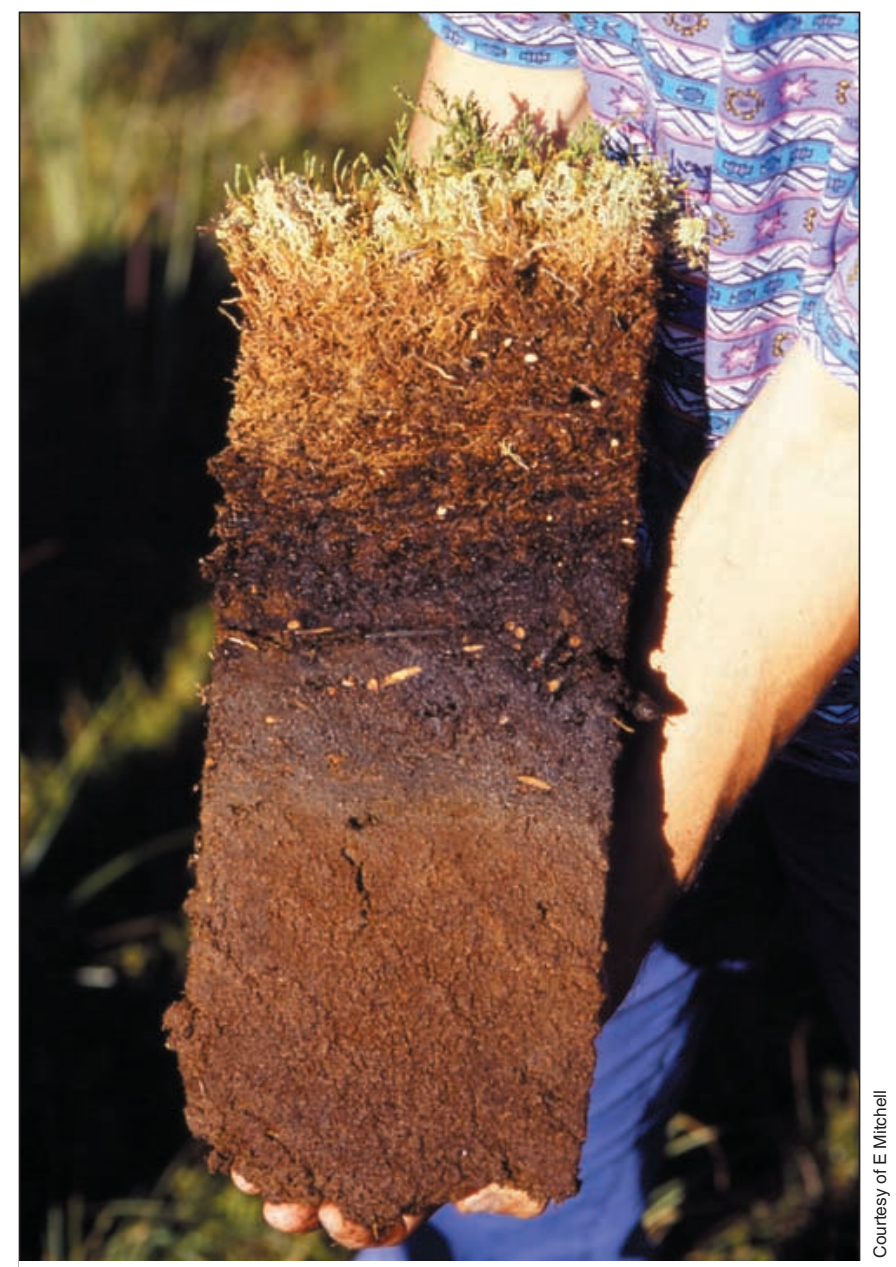

Figure 3. Peat profile taken on a mined peatland where successful regeneration has occurred through initial colonization by the moss Polytrichum strictum and later recolonization by Sphagnum fallax. The former peat surface is visible at the bottom. The dark brown layer is the former peat surface that has undergone partial decomposition under oxygenated conditions. The less decomposed, lighter brown peat with recognizable plant remains lies above, and the living mosses and vascular plants are at the top.

tion, erosion, water reservoirs, and other uses. Total losses add up to approximately $500000 \mathrm{~km}^{2}$, approximately the area of Spain. This represents about $16 \%$ of peatlands' former extent. Today, however, losses are due almost entirely to agriculture and forestry (>99.8\%), whereas losses due to peat extraction are very minor $(<0.2 \%)$ (Joosten and Clarke 2002). Since the 1950s, for example, Finland has lost $60 \%$ of its former extensive active peatland area to forestry and many of the more fertile peatlands (fens) had been used for agriculture long before then (Heikkilä and Lindholm 2000).

\section{Global vs regional loss: conservation issues}

On the global scale, it is unclear whether the amount of peat being harvested exceeds what is being accumulated in natural peatlands. Some authorities suggest accumula- 


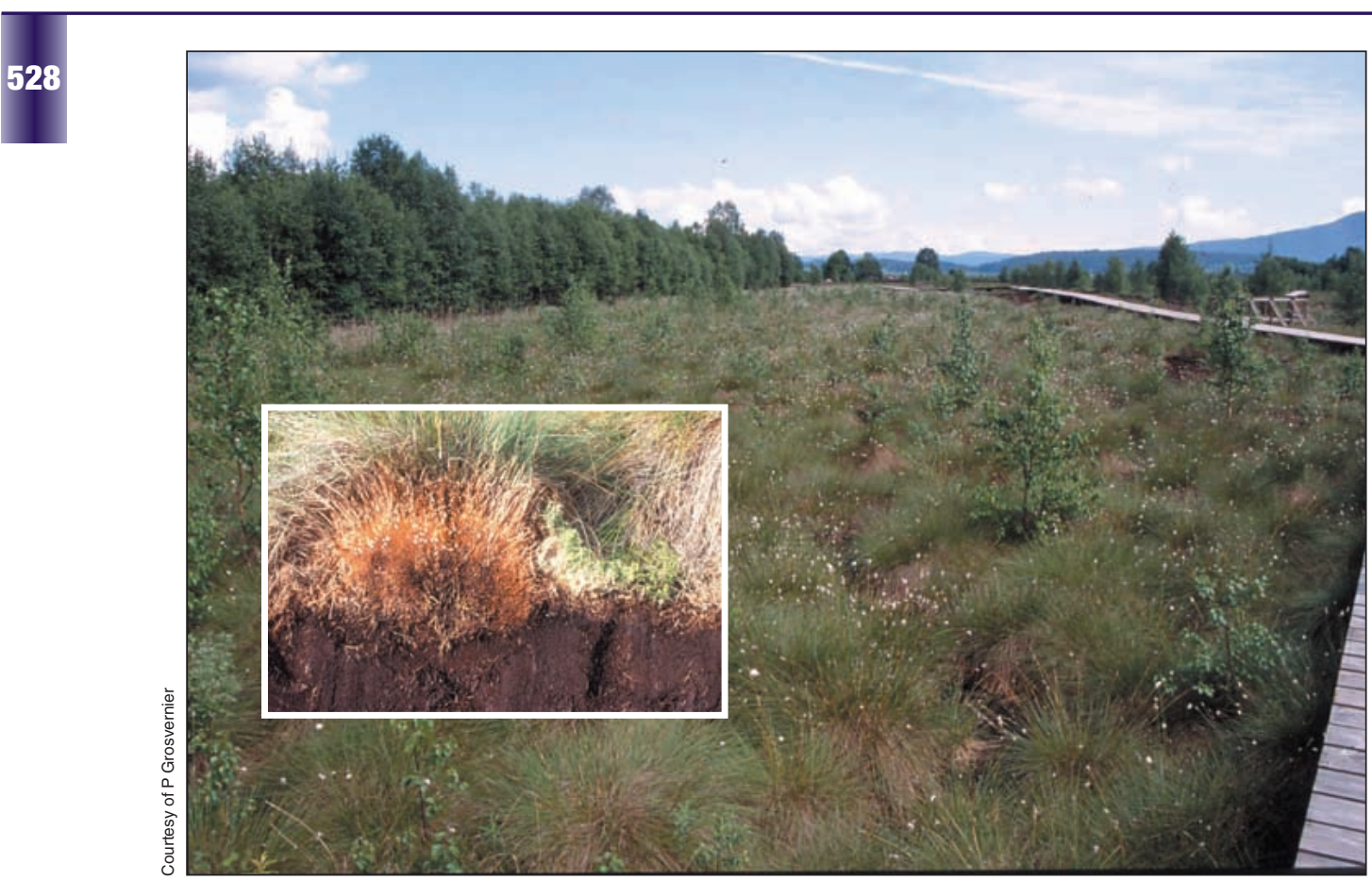

Figure 4. Sphagnum recolonization under the protection of cottongrass Eriophorum vaginatum, growing over a former bare peat surface in the Swiss Jura Mountains. Inset shows sliced tussock with Sphagnum growing between two tussocks.

tion exceeds losses (Gorham 1991b), while others indicate the reverse (Schilstra 2001; Joosten and Clarke 2002). This partially depends upon the definitions used, as well as whether one is considering peat itself or the $\mathrm{C}$ that comes from it, which may not be totally lost when the peat is used in horticulture or agriculture.

The total peat budget, however, is only part of the story. Most peat mining takes place close to urban areas, mainly in locations with easy access. In contrast, most pristine peatlands are located in remote places such as the Hudson Bay lowlands and western Siberia, where mining will probably never be economically viable for logistical reasons (Joosten and Clarke 2002). In central Europe, southern Québec, and southern Ontario, considerable proportions of the original peatland surfaces have been lost (Gorham 1991a; Lindsay 1993; Desrochers et al. 2000; Joosten and Clarke 2002), but more peatlands are being protected in the less accessible areas. For example, $70 \%$ of the protected peatlands in Sweden are in the north of the country (Egelmark 2000), while in Finland, although 9\% of the peatlands are protected, this drops to only $3 \%$ in the southern regions (Heikkilä and Lindholm 2000). Even more extreme is the case of the southern St Lawrence River region of Québec, where only one out of 150 bogs are currently protected (Desrochers et al. 2000).

Peatlands located in the more southern regions are different from ones located further north; they often have distinct faunas and floras or isolated and possibly genetically divergent populations of circum-boreal species (Desrochers et al. 2000). Furthermore, they often contain a longer paleoenvironmental record, as this peat started to accumulate when the more northern locations were still under ice (Halsey et al. 1998; Halsey et al. 2000). Therefore, despite what may be true on a global scale, peatlands might not be interchangeable when assessing their value and function at regional or local scales.

\section{Management approaches}

Depending on the present state of a peatland, we can identify four main management strategies.

\section{Conservation}

Undisturbed sites of high scientific and biodiversity value may be set aside for conservation as natural heritage. Extraction is not compatible, and management of these sites is usually limited.

\section{Restoration}

Disturbed peatlands may be restored to conditions similar to pristine sites. This may help countries balance their $\mathrm{C}$ budget, or at least reduce their net $\mathrm{C}$ emission. This would lead to the restoration of degraded peatlands left over after mining, or currently used for agriculture, which have been identified as major sources of $\mathrm{CO}_{2}$ (KasimirKlemedtsson et al. 1997). In the temperate and boreal zones, restoration usually aims at reestablishing Sphagnum mosses (Rochefort 2000). However, abandoned mined sites are often left with a complex topography that may hinder the successful re-establishment of important species (eg Sphagnum mosses). In such cases, it may be best to further extract a limited amount of peat, or to modify the topography to restore the site's hydrology (Bugnon et al. 1997; Price et al. 2002). Traditional peat cutting often left favorable conditions (ie patchy structures with ditches; Figure 5), while industrial exploitation, which scrapes the topsoil from large areas, is much more problematic (Figures 2 and 6).

Favorable microclimatic conditions are required for a successful Sphagnum recolonization (Grosvernier et al. 1995; Campeau and Rochefort 1996; Buttler et al. 1998; Rochefort and Bastien 1998). In the case of spontaneous regeneration, these conditions are often provided by companion keystone species - usually either mosses such as Polytrichum strictum (Figure 3) or herbaceous plants such as Eriophorum vaginatum (Figure 4) that are able to grow 
directly on the bare peat (Grosvernier et al. 1995; Robert et al. 1999). Spontaneous regeneration is the exception rather than the rule, however. In the Swiss Jura Mountains, only $25 \%$ of the abandoned cutover bog surfaces that have not been colonized by trees show signs of spontaneous regeneration (Matthey 1996), while less than $10 \%$ of the surface of a peatland in Québec showed Sphagnum recolonization 30 years after abandonment (Price and Whitehead 2001).

In some cases the restoration of peatlands at least appears to be feasible, with the return of some pioneer species. However, the re-establishment of a typical bog community has not yet been observed (Feldmeyer-Christe et al. 2001), and the long-term evolution of these secondary sites remains unclear (Gorham and Rochefort 2003). We need to better understand why regeneration succeeds in some cases and not in others. We also need to

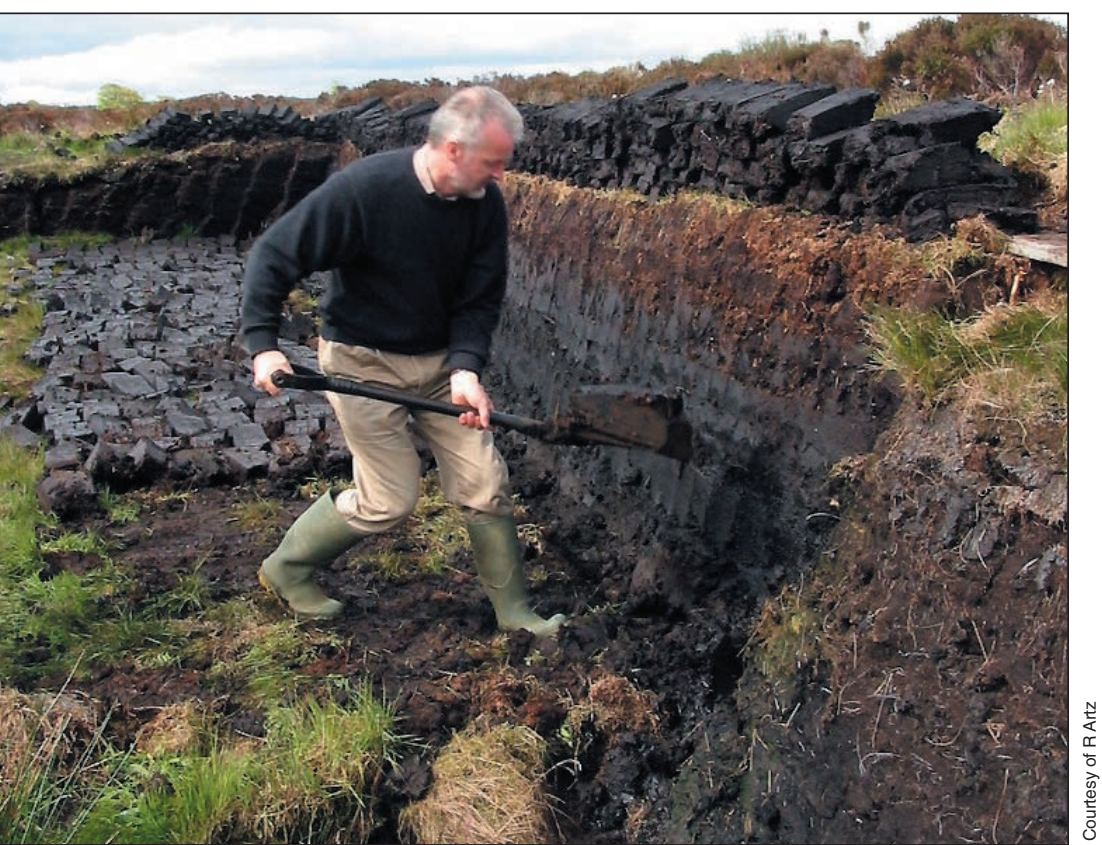

Figure 5. Traditional peat cutting in Scotland. This kind of relatively low-impact exploitation of peatlands may increase biodiversity by recreating transitional habitats. monitor the evolution of restored sites, to determine that their structure and function can indeed be compared to those of pristine sites, or that they are at least heading in the right direction in terms of the re-establishment of biodiversity and long-term $\mathrm{C}$ sequestration. The question is, which indicators should we be using to monitor the success of restoration?

\section{Rehabilitation}

After disturbance, transitional bog habitats with high biodiversity, and/or representing habitat for rare species, can be maintained or recreated through the removal of peat; this has real potential for reconciling peat exploitation with biodiversity issues. These habitats may be locally rare, or may have disappeared altogether due to natural succession.

In countries such as Switzerland, where the total surface area of remaining peatlands is small, several rare or endangered species now benefit from secondary habitats created by former peat extraction activities. These include the peat mosses Sphagnum affine, Sphagnum contortum, Sphagnum fimbriatum, Sphagnum teres, and Sphagnum warnstorfii, which are restricted to fens or often found in secondary bog vegetation (Feldmeyer-Christe et al. 2001), as well as dragonfly species such as Leucorrhinia pectoralis, Aeshna subarctica, Lestes virens vestalis, and Coenagrion hastulatum. The latter are found in the transitional habitats that often develop in peat extraction ditches (eg SphagnoUtricularion, Caricion lasiocarpae, or Magnocaricion plant communities), but are absent from the late-succession stages of bog development (Delarze et al. 1998). In Sweden, it was found that the regional diversity of peat mosses had been increased in old hand-cut pits after spon- taneous regeneration (Soro et al. 1999). Some northern species (eg Sphagnum lindbergii) not found in pristine mire vegetation in more southern areas could nevertheless be found in these local pits.

Small isolated wetlands play a much larger role in the

\section{Definitions}

Peatland: area with or without vegetation with a naturally accumulated peat layer at the surface

Mire: a peatland where peat is currently being formed

Bog: a mire that receives most or all of its water supply from rainfall; usually nutrient-poor and raised above the adjacent land

Fen: a mire that forms in a land depression and receives water from groundwater; usually nutrient-rich

Wetlands: ecosystems that have shallow water or flooded soils for part of the growing season, have organisms adapted to this wet environment, and have soil indicators of this flooding

Mire ecosystems are characterized by the unique ability to accumulate and store dead organic matter from Sphagnum and many other non-moss species as peat, under conditions of almost permanent water saturation. Sites that are no longer accumulating peat, including mined or cutover peat, would not be considered mires.

(Mitsch and Gosselink 2000; Joosten and Clarke 2002) 


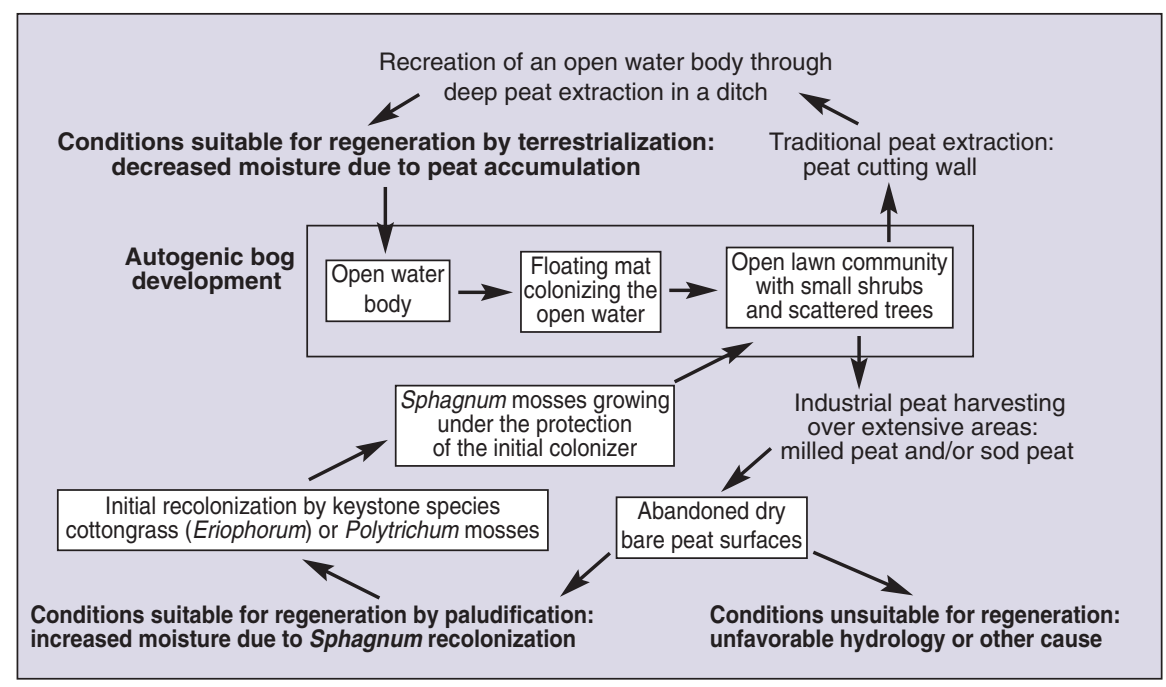

Figure 6. Simplified diagram of the natural vegetation succession leading to Sphagnumdominated peatlands and how these communities may change following peat harvesting. Peatlands often result from the infilling of a water body by aquatic vegetation followed by the establishment of sedge communities. Peat harvesting reduces the peat thickness either homogeneously, if extensive surfaces are harvested industrially, or heterogeneously, when done in a traditional manner. The patterns, speed, and likelihood of regeneration differ, and one of the aims of project RECIPE is to understand the determinants of these regeneration patterns.

maintenance of biodiversity than their size would suggest (Gibbs 1993). By increasing habitat diversity, limited peat exploitation can help sustain endangered species by reducing the distance between favorable habitats, thereby allowing easier migration. The goal of the rehabilitation strategy is to prevent the loss of species linked to ephemeral habitats with a strong dynamic and high $\mathrm{C}$ sequestration potential.

For sustainable exploitation to be possible, the proportion of the total surface being harvested in any one year should be small enough to allow previously harvested areas to reach the desired successional stage before they are due for harvesting again. Recolonization of the peat surface by pioneer species is not enough; the time between two successive harvests must be long enough (decades or even centuries) to allow secondary succession to reach the original typical bog community. Indeed, the observation of pristine and exploited Irish peatlands has revealed how sensitive Sphagnum bog species are to repeated peat cutting (Cooper et al. 2001), while in Canada, bird communities characteristic of natural bogs have failed to return to cutover sites, even several decades after abandonment (Desrochers et al. 1998). The rotation approach is similar to traditional slash-and-burn agriculture and situations in which a relatively small proportion of the total area is clear-cut every year. In both cases, the system can only support a relatively minor exploitation pressure.

Although this approach is clearly compatible with the maintenance or even the enhancement of biodiversity, and could result in a steady state in $\mathrm{C}$ being reached with no further sequestration of the element, it will have clear impacts on the ongoing $\mathrm{C}$ storage capacity of the peat- land, and will also cause some loss of the historical and paleoenvironmental records (Buck-land 1993). We need to understand the patterns and processes of this dynamic, both to find reliable indicators of ecosystem function and to set up sound monitoring programs to assess the consequences of rehabilitation.

\section{Conversion}

Even when most of the peat has been removed, former peatlands may acquire a high value for nature conservancy. If these degenerate surfaces are converted into extensively used agricultural sites (ie lightly grazed or cut), they may then constitute a vital habitat for rare or endangered species as, for example, nutrient-poor, species-rich wet hay meadows. This goal may be compatible with a general policy to reduce the emission of $\mathrm{CO}_{2}$ from organic soils or even restore their $\mathrm{C}$ sequestering capacity (KasimirKlemedtsson et al. 1997; Craft and Richardson 1998). Managers need to know what the requirements of rare and endangered species are, to optimize the ecological value of these surfaces. Here, too, a monitoring program will be required.

\section{A new research initiative to improve management}

In order to provide information to give conservationists and peat extraction managers options to restore peat accumulation and $\mathrm{C}$ sequestration in peatlands that have either been abandoned or designated for restoration, we initiated a project called Reconciling Commercial Exploitation of Peat with Biodiversity in Peatland Ecosystems (RECIPE) (www.nbu.ac.uk/biota/recipe_page . $\mathrm{htm}$ ). The project's objectives are to (1) perform a socioeconomic appraisal of the current impact of peatland utilization and restoration practices; (2) identify combinations of water table, vegetation, microbiology, and chemistry favorable to the re-establishment of peatland biodiversity, $\mathrm{C}$ sequestration, and long-term regeneration; (3) develop guidelines for sustainable management; and (4) quantify future requirements for sustainable peatland management, recognizing its value within the rural economy.

A particular innovation of this research effort is the combination and synthesis of ecological, management, and socioeconomic approaches. By achieving these objectives in the context of current management practices, RECIPE will provide guidelines for sustainable management that will reconcile peat use with the maintenance of 
biodiversity. Studies will be made in a range of regenerating peatlands, from bare peat to well-established secondary vegetation, including gradients of latitude and/or climate, fertility, and anthropogenic influence, as well as field regeneration experiments in four locations in Europe. The net impact of different keystone plant species will be assessed in these experiments. The ultimate goal is to develop indicators of change in the physical, chemical, and biological characteristics of peat.

\section{Which indicators should we use?}

There is no a priori reason to believe that one biological, physical, or chemical indicator is more appropriate than another. Indeed, different taxonomic groups respond differently to environmental gradients and ecosystem dynamics (Francez et al. 2000; Mitchell et al. 2000). Some groups seem to be the engineers of the observed changes in ecosystem structure, but this is often unclear. For example, Sphagnum moss is clearly a key player in peatland regeneration, but its re-establishment on bare peat usually requires a companion species. However, the development of a dense Sphagnum carpet does not seem to be enough to restore important processes such as C sequestration (Francez et al. 2000). This is a case where ecosystem structure and function are disconnected.

Other indicators could therefore be more appropriate for this, including microbes (Gilbert et al. 1998; Croft et al. 2001), testate amoebae (Buttler et al. 1996; Mitchell et al. 1999; Charman 2001), vertebrates (Desrochers et al. 1998; Mazerolle et al. 2001), and biochemical or physical markers (Francez and Vasander 1995; Bourdon et al. 2000). Because they react faster than other indicators, microorganisms and biochemical markers are especially interesting for monitoring purposes (Warner and Chmielewski 1992). One solution is to combine a wide range of indicators and measurements of ecosystem processes (eg vegetation, microorganism diversity, chemical and physical markers, and ecosystem level measurements), in order to clarify the relationships between biological, chemical, and physical indicators and the rate at which they change during peatland regeneration.

\section{Sensitivity to environmental gradients and global change}

Natural ecosystems are increasingly affected by global change, even where no direct impact is noticeable, and indeed peatlands are sensitive to changes in precipitation and atmospheric deposition (Lee 1998; Moore 2002). The potential for mined peatlands to regenerate depends on the characteristics of the leftover surface (eg soil, vegetation), the regional climate (precipitation, pollution) and hydrology, as well as on legal and cultural issues. But anthropogenic influences, such as $\mathrm{N}$ deposition rates and increased atmospheric $\mathrm{CO}_{2}$ concentration, may also affect the outcome of the regeneration process and the feasibility of rehabilitation, as they do for natural ecosystems (Mitchell et al. 2002). To assess the importance of some of these sources of variability, research on peatland regeneration should cover a wide range of climatic and human influences.

\section{Conclusions}

Despite the potential for a sustainable use of peatlands, some pristine sites need to be preserved in all regions. One of the reasons for this is the conservation of paleoenvironmental records (Buckland 1993; Bourdon et al. 2000), since the techniques for environmental reconstruction are constantly changing and we can expect that future scientists will be able to gain much more information from the analysis of peat stratigraphy than we can now (Joosten and Clarke 2002). By revealing the developmental history of peatlands, paleoecologists can also provide crucial information for restoration (Gorham and Rochefort 2003). In addition, preserved peatlands may contribute to ecotourism - they are local illustrations of a unique habitat with a unique biodiversity and natural heritage value. At the same time, limited peatland exploitation supports a certain sector of the rural economy, with other industries dependant upon the peat produced.

If we are to use peatlands in a truly wise way, we need to make sure their exploitation is sustainable, not just globally, but within homogeneous biogeographical regions and within a human timescale. We should preserve both biodiversity and a network of intact sites by carefully planning the uses to which peatlands will be subjected.

\section{Acknowledgements}

RECIPE is supported by the European Commission, Directorate I, under the "Energy, Environment and Sustainable Development" program (EVK2-2002-00269) and by the Swiss Federal Office for Education and Science (OFES).

\section{- References}

Barber KE. 1993. Peatlands as scientific archives of biodiversity. Biodivers Conserv 2: 474-89.

Bourdon S, Laggoun-Défarge F, Disnar J-R, et al. 2000. Organic matter sources and early diagenetic degradation in a tropical peaty marsh (Tritrivakely, Madagascar): implications for environmental reconstruction during the Sub-Atlantic. Org Geochem 31: 421-38.

Buckland PC. 1993. Peatland archaeology: a conservation resource on the edge of extinction. Biodivers Conserv 2: 513-27.

Bugnon JL, Rochefort L, and Price JS. 1997. Field experiment of Sphagnum reintroduction on a dry abandoned peatland in Eastern Canada. Wetlands 17: 513-17.

Buttler AJ, Grosvernier P, and Matthey Y. 1998. Development of Sphagnum fallax diaspores on bare peat with implications for the restoration of cut-over bogs. J Appl Ecol 35: 800-10.

Buttler AJ, Warner BG, Grosvernier P, and Matthey Y. 1996. Vertical patterns of testate amoebae (Protozoa: Rhizopoda) and peat-forming vegetation on cutover bogs in the Jura, Switzerland. New Phytol 134: 371-82. 
Campeau S and Rochefort L. 1996. Sphagnum regeneration on bare peat surfaces: field and greenhouse experiments. J Appl Ecol 33: 599-608.

Charman DJ. 2001. Biostratigraphic and palaeoenvironmental applications of testate amoebae. Quaternary Sci Rev 20: 1753-64.

Clymo RS, Turunen J, and Tolonen K. 1998. Carbon accumulation in peatland. Oikos 81: 368-88.

Cooper A, McCann TP, and Hamill B. 2001. Vegetation regeneration on blanket mire after mechanized peat-cutting. Global Ecol Biogeogr 10: 275-89.

Craft CB and Richardson CJ. 1998. Recent and long-term organic accretion and nutrient accumulation in the Everglades. Soil Sci Soc Am J 62: 834-43.

Croft M, Rochefort L, and Beauchamp CJ. 2001. Vacuum-extraction of peatlands disturbs bacterial population and microbial biomass carbon. App Soil Ecol 18: 1-12.

Delarze R, Gonseth Y, and Galland P. 1998. Guide des milieux naturels de Suisse: écologie-menaces-espèces caractéristiques. Lausanne, Switzerland: Delachaux et Niestlé.

Desrochers A, Rochefort L, and Savard JPL. 1998. Avian recolonization of eastern Canadian bogs after peat mining. Can J Zool 76: 989-97.

Desrochers A, Lavoie C, Pellerin S, and Poulin M. 2000. Bog conservation: a Canadian perspective. In: Rochefort L and Daigle JY (Eds). Sustaining our peatlands. Proceedings of the 11th International Peat Congress, Vol 2; August 6-12, 2000; Edmonton, Canada: Canadian Society of Peat and Peatlands \& International Peat Society. p 1034-37.

Egelmark R. 2000. Man and the peat: a Swedish perspective. In: Rochefort L and Daigle JY (Eds). Sustaining our peatlands. Proceedings of the 11th International Peat Congress, Vol 2; August 6-12, 2000; Edmonton, Canada: Canadian Society of Peat and Peatlands \& International Peat Society. p 1027-33.

Feldmeyer-Christe E, Schnyder N, and Bisang I. 2001. Distribution and habitats of peat mosses, Sphagnum, in Switzerland. Lindbergia 26: 8-22.

Francez AJ, Gogo S, and Josselin N. 2000. Distribution of potential $\mathrm{CO}_{2}$ and $\mathrm{CH}_{4}$ productions, denitrification and microbial biomass $\mathrm{C}$ and $\mathrm{N}$ in the profile of a restored peatland in Brittany (France). Eur J Soil Biol 36: 161-68.

Francez AJ and Vasander H. 1995. Peat accumulation and peat decomposition after human disturbance in French and Finnish mires. Acta Oecol 16: 599-608.

Gilbert D, Amblard C, Bourdier G, and Francez AJ. 1998. The microbial loop at the surface of a peatland: structure, function, and impact of nutrient input. Microbial Ecol 35: 83-93.

Gibbs JP. 1993. Importance of small wetlands for the persistence of local populations of wetland-associated animals. Wetlands 13: 25-31.

Girard M, Lavoie C, and Theriault M. 2002. The regeneration of a highly disturbed ecosystem: a mined peatland in southern Québec. Ecosystems 5: 274-88.

Gorham E. 1991a. Human influences on the health of northern peatlands. Trans Roy Soc Can 6: 199-208.

Gorham E. 1991b. Northern peatlands: role in the carbon cycle and probable responses to climatic warming. Ecol Appl 1: 182-95.

Gorham E and Rochefort L. 2003. Peatland restoration: a brief assessment with special reference to Sphagnum bogs. Wetlands Ecol Manage 11: 109-19.

Grosvernier P, Matthey Y, and Buttler AJ. 1995. Microclimate and physical properties of peat: new clues to the understanding of bog restoration processes. In: Robertson RA (Ed). Restoration of temperate wetlands. Chichester, UK: John Wiley \& Sons. p 437-50.

Halsey LA, Vitt DH, and Bauer IE. 1998. Peatland initiation during the Holocene in continental western Canada. Climatic
Change 40: 315-342.

Halsey LA, Vitt DH, and Gignac LD. 2000. Sphagnum-dominated peatlands in North America since the last glacial maximum: their occurrence and extent. Bryologist 103: 334-52.

Heikkilä R and Lindholm T. 2000. Conservation of the biodiversity of mires in Finland. In: Rochefort L and Daigle JY (Eds). In: Rochefort L and Daigle JY (Eds). Sustaining our peatlands. Proceedings of the 11th International Peat Congress, Vol 2; August 6-12, 2000; Edmonton, Canada: Canadian Society of Peat and Peatlands \& International Peat Society. p 1038-43.

Joosten H and Clarke D. 2002. The wise use of mires and peatlands. International Mire Conservation Group and International Peat Society.

Kasimir-Klemedtsson A, Klemedtsson L, Berglund K, et al. 1997. Greenhouse gas emissions from farmed organic soils: a review. Soil Use Manage 13: 245-50.

Lappalainen E. 1996. Global peat resources. Jyskä, Finland: International Peat Society.

Lee JA. 1998. Unintentional experiments with terrestrial ecosystems: ecological effects of sulfur and nitrogen pollutants. J Ecol 86: $1-12$.

Lindsay RA. 1993. Peatland conservation - from cinders to Cinderella. Biodivers Conserv 2: 528-40.

Matthey Y. 1996. Conditions écologiques de la régénération spontanée du Sphagnion magellanici dans le Jura Suisse (typologie, pédologie, hydrodynamique et micro-météorologie) ( $\mathrm{PhD}$ thesis). Neuchâtel, Switzerland: University of Neuchâtel.

Mazerolle MJ, Drolet B, and Desrochers A. 2001. Small mammal responses to peat mining of southeastern Canadian bogs. Can J Zool 79: 296-302.

Mitchell EAD, Buttler AJ, Warner BG, and Gobat JM. 1999. Ecology of testate amoebae (Protozoa: Rhizopoda) in Sphagnum peatlands in the Jura mountains, Switzerland and France. Ecoscience 6: 565-76.

Mitchell EAD, Buttler AJ, Grosvernier P, et al. 2000. Relationships among testate amoebae (Protozoa), vegetation and water chemistry in five Sphagnum-dominated peatlands in Europe. New Phytol 145: 95-106.

Mitchell EAD, Buttler AJ, Grosvernier P, et al. 2002. Contrasted effects of increased $\mathrm{N}$ and $\mathrm{CO}_{2}$ supply on two keystone species in peatland restoration and implications for global change. $J$ Ecol 90: 529-33.

Mitsch WJ and Gosselink JG. 2000. Wetlands, 3rd ed. New York: John Wiley \& Sons.

Moore PD. 2002. The future of cool temperate bogs. Environ Conserv 29: 3-20.

Price JS and Whitehead GS. 2001. Developing hydrologic thresholds for Sphagnum recolonization on an abandoned cutover bog. Wetlands 21: 32-40.

Price JS, Rochefort L, and Campeau S. 2002. Use of shallow basins to restore cutover peatlands: hydrology. Restor Ecol 10: 259-66.

Robert EC, Rochefort L, and Garneau M. 1999. Natural revegetation of two block-cut mined peatlands in eastern Canada. Can J Bot 77: 447-59.

Rochefort L. 2000. New frontiers in bryology and lichenology. Sphagnum - a keystone genus in habitat restoration. Bryologist 103: 503-08.

Rochefort L and Bastien DF. 1998. Reintroduction of Sphagnum into harvested peatlands: evaluation of various methods for protection against desiccation. Ecoscience 5: 117-27.

Schilstra AJ. 2001. How sustainable is the use of peat for commercial energy production? Ecol Econ 39: 285-93.

Soro A, Sundberg S, and Rydin H. 1999. Species diversity, niche metrics and species associations in harvested and undisturbed bogs. J Veg Sci 10: 549-60.

Warner BG and Chmielewski JG. 1992. Testate amoebae (Protozoa) as indicators of drainage in a forested mire, northern Ontario, Canada. Arch Protistenkd 141: 179-83. 